\title{
The essential oil of Brazilian pepper, Schinus terebinthifolia Raddi in larval control of Stegomyia aegypti (Linnaeus, 1762)
}

Ary G Silva ${ }^{1 *}$, Drielle L Almeida ${ }^{1}$, Silas N Ronchi ${ }^{1}$, Amarildo C Bento ${ }^{2}$, Rodrigo Scherer ${ }^{3}$, Alessandro C Ramos ${ }^{1}$, Zilma MA Cruz ${ }^{1}$

\begin{abstract}
Background: The ability of mosquitoes of the genus Aedes and its allies, such as Stegomyia, to transmit diseases such as dengue and yellow fever, makes them important in public health. This study aims to evaluate the use of the essential oil of Brazilian pepper in biological control of by assessing and quantifying the larvicidal effect against S. aegypti, the only available access to dengue control, and test its risk of genotoxicity with Salmonella typhimurium as an indicator of safety for its environmental use.
\end{abstract}

Results: The density of the oil was $0.8622 \mathrm{~g} \mathrm{~mL}^{-1}$. Gas chromatography coupled with mass spectrometry revealed six major constituents: $\delta$-3-carene (55.43\%), $\alpha$-pinene (16.25\%), sylvestrene (10.67\%), germacrene D (2.17), $\beta$-myrcene (1.99\%), and isoterpinolene (1.4\%). The minimum inhibitory dose to larvae development was $862.20 \mu \mathrm{g}$ $\mathrm{mL}^{-1}$. The median lethal dose $\left(\mathrm{LD}_{50}\right)$ of the essential oil for larvae was between the concentrations of 172.44-344.88 $\mu \mathrm{g} \mathrm{mL}{ }^{-1}$. There was no mutagenic risk for the essential oil, since there were no biochemical or morphological changes in S. typhimurium after exposure to the essential oil.

Conclusions: The minimum inhibitory essential oil concentration and the median lethal dose pointed to the value of the use of water dispersions of Brazilian pepper essential oil as an environmental safe natural larvicidal for S. aegypti.

\section{Introduction}

Dengue was eradicated in Brazil in 1955, but outbreaks of this tropical disease have been occurring since the $70 \mathrm{~s}$ [1]. In fact, dengue is an enormous local as well as a global problem, because in a hundred million households all over the world, $S$. aegypti is perfectly adapted. This makes the commensal virus that this insect harbors also perfectly adapted to its domesticity, exposing some 2.5 billion people in tropical and subtropical countries to a serial infection of at least one of the four serotypes that have evolved [2].

Because of the growing worldwide burden of dengue fever, it is expected that there will be a corresponding impact on the health sector as well as on the global economy. Total mean costs in International Dollars

\footnotetext{
* Correspondence: arygomes@uvv.br

${ }^{1}$ Centro Universitário Vila Velha - UW. Rua Comissário José Dantas de Melo,

21, Boa Vista, Vila Velha, ES, CEP 29.102-770, Brazil

Full list of author information is available at the end of the article
}

were estimated in I $\$ 514$ and I $\$ 1,394$, for each ambulatory and each hospitalized case, respectively, in five American countries (Brazil, El Salvador, Guatemala, Panama, and Venezuela) and three Asian countries (Cambodia, Malaysia, and Thailand). With an annual average of 574,000 cases reported, the aggregate annual economic cost of dengue for the eight study countries is at least I\$587 million. With an adjustment for underreporting could raise this total to $\$ 1.8$ billion, and incorporating costs of dengue surveillance and vector control would raise the amount further [3].

One of the main reasons for the rise of epidemics, such as dengue, is the high human population density and unplanned urbanization [4], allied with the high level of domesticity of its vector [2]. The mosquito that acts as the dengue fever vector is $S$. aegypti (Linnaeus, 1762), a new combination for Aedes aegypti [5], and it has morphological characteristics that make its identification easy, such as brown wings and a silver-white
Ciomed Central

(c) 2010 Silva et al; licensee BioMed Central Ltd. This is an Open Access article distributed under the terms of the Creative Commons Attribution License (http://creativecommons.org/licenses/by/2.0), which permits unrestricted use, distribution, and reproduction in any medium, provided the original work is properly cited. 
strip on each side of its thorax [6,7]. They are long distance flyers and are attracted by hosts and by the interaction of physical, chemical, biological and sensorial factors, such as vision and olfaction. Their control can be accomplished in several ways, through chemical, physical, biological and integrated methods $[6,8]$.

The lack of urban planning, sanitation, surveillance, education, and information are intrinsic factors to the challenges of this disease and its vector control [9]. Besides these facts, a major problem for this disease is the lack of vaccines and drugs, which development is complicated by the fact that dengue virus exists as four distinct serotypes. Therefore, a broad robust immune response must be induced simultaneously against all four serotypes while avoiding exacerbating the potential risk of developing the dengue diseases through incomplete immune responses [10]. Therefore, disease control comprises five major components: selective integrated vector control, with community and intersectoral participation; active disease surveillance based on a strong health-information system; emergency preparedness; capacity building and training; and vector-control research [11], especially blocking its reproduction that can occur in any receptacle that accumulates water [12].

Considering the damage caused by diseases such as dengue in tropical and subtropical countries [2], and the biodiversity of plant species in the tropics, studies on the use of plant natural products that demonstrate potential larvicidal effect have increased [13]. Because natural products are usually considered not to disturb the natural ecological balance, besides being naturally available and economically viable [14], and, in nature, they correspond to phytochemicals that were predominantly secondary compounds produced by plants and that protects themselves against herbivorous insects [13].

All over the world, phytochemicals of citronella oil have been used as insect repellents since 1901 [15], and since 1947, there have been several reports of a large number of botanical insecticides containing a wide spectrum of bioactive components, including insecticides [16]. Research attention was focused on the use of South American plants in larvae control of S. aegypti at the end of 20th century, concerning plant crude extracts, but without indication of any phytochemicals involved in that effect [17].

Considering Brazilian plant species diversity, this trend to make wide screenings of larvicidal plant extracts is still followed $[18,19]$ and some authors have demonstrated biological activity against the larvae of S. aegypti. Using the oil, the essential oil, and ethanolic extracts, also with no elucidation of their phytochemical constitution, 17 plants have shown larvicidal activity [20]. The phytochemical nature of some of the Brazilian natural products has been pointing to terpenes, mainly monoand sesquiterpenoids, and phenylpropanoids as the active larvicidal constituents [21]. The essential oils achieved more importance in larvicidal screening of plant derivatives and extracts studied in Brazil, even when the plants studied were exotic [22], but the native sources of essential oil were still the investigative focus [23-27], mainly because of the interest in searching for environmentally safe insecticides [27].

Schinus terebenthifolia Raddi (Anacardiaceae), commonly known as Brazilian pepper, is an evergreen tree, native of South America, especially Brazil, Paraguay and Argentina. The fruits are drupes and have green color when they are immature, and become dark pink or red, in maturity [28], with one dark brown seed per fruit [29]. The essential oil of the vegetative parts showed non-steroidal anti-inflammatory activity by inhibiting phospholipase A2 [30], acting by competitive inhibition of this specific enzyme [31] due to one of its components, schinolmasticadienoic acid [32]. Its healing activity was also directly related to triterpenoids present in fruits [33]. The essential oil also showed antimicrobial activity by several substances, such as terebinthone, hydroxymasticadienoic, terebinthifolic, and ursolic acids [34], and antifungal activity was also evidenced [35].

Since there is no information about the use of the essential oil of $S$. therebintifolia in larval control of $S$. aegypti, this study aims to investigate biological control of this mosquito by the use of essential oil of Brazilian pepper, as well as to assess and quantify the larvicidal effect, and to evaluate its risk of genotoxicity in Salmonella typhimurium ATCC 14028, as an indicator of safety for environmental use.

\section{Methods}

\section{Essential oil extraction; purification, and density} determination

Fruits of the Brazilian pepper tree were collected from specimens occurring in the region of Vitória, Espírito Santo, Brazil, and $250.0 \mathrm{~g}$ of those fruits were separated from any impurities in the Laboratory of Plant Ecology, at the Centro Universitário Vila Velha - UVV.

The extraction of essential oil was made by hydrodistillation in a Clevenger apparatus with the crunched fruits and seeds, during one hour of the extraction process. This procedure was performed in the laboratory of Chemical Sciences, at UVV.

After extraction, the essential oil was transferred to a glass vial, and its purification was made by separation of the remnant water by freezing, and the essential oil which was kept in liquid phase, was drained from the vial.

The density of the essential oil was gravimetrically determined by weighing $1 \mathrm{~mL}$ of liquid at $20^{\circ} \mathrm{C}$, using a 
temperature-controlled water bath. The essential oil was weighed in an analytical balance with accuracy of $1.0 \mathrm{mg}$.

\section{Chromatographic Analysis}

The identification of the essential oil components was carried out by high resolution gas chromatography analysis, in the Fine Chemistry Laboratory, at Tommasi Analítica. The injection volume was $2 \mu \mathrm{L}$, composed of $1.6 \mathrm{~mL}$ of a solution of essential oil $(30 \mathrm{mg} / \mathrm{ml})$ and $0.4 \mathrm{~mL}$ of a solution of hydrocarbon series of C7-C30, as internal standard, both in $n$-hexane as solvent.

The gas chromatography coupled with mass spectrometry - GC-MS - system used consisted of a gas chromatograph, Thermo Scientific ${ }^{\circ}$ Ultra GC coupled to a mass spectrometer, Thermo Scientific ${ }^{\circ}$. The fused silica capillary column used was a DB-5 J \& W Scientific $(30 \mathrm{~m} \times 0.25 \mathrm{~mm} \times 0.25 \mathrm{~mm})$. Helium was the carrier gas and the column temperature program was increased by $3^{\circ} \mathrm{C}$ per minute between $60^{\circ}-240^{\circ} \mathrm{C}$. The mass spectra were obtained at $70 \mathrm{eV}$ at a scan rate of $0.84 \mathrm{scan} / \mathrm{sec}$, at the range $\mathrm{m} / \mathrm{z}$ 40-500 [36].

The retention times of sample components and a mixture of $n$-alkanes from C7-C30, co-injected into the GCMS system under the same temperature program were used for the calculation of the Kovats Retention Index KI [36]. Identification of essential oil components was based on the calculated KI compared with the available literature [36], and mass spectra with the GC-MS spectral library.

\section{Biological assay with larvae of Stegomyia aegypti}

Larvae of $S$. aegypti in the third instar were obtained after incubation of eggs in the Laboratory of Biomarkers of Environmental Contamination and Genotoxicity, at UVV, using $2,000 \mathrm{~mL}$ of distilled water with natural food for fish, composed of dried cysts and eggs of planktonic organisms. The eggs of $S$. aegypti were supplied by the Center for Zoonosis Control from the Health Department at Vitoria, Espírito Santo state, Brazil.

A series of tubes was prepared in five replicates for each control, blank and treatment performed, and each replicate received 10 larvae, including a control with distilled water, and a blank with an aqueous solution of $0.5 \%$ Tween 80 that was used as dispersing medium for the essential oil and exposure of larvae to treatment.

Since the lethal dose of the essential oil was $862.20 \mu \mathrm{g}$ $\mathrm{mL}^{-1}$ [37], a concentration gradient was prepared, ranging from 86.22 up to $862.20 \mu \mathrm{g} \mathrm{m}^{-1}$, by the oil dispersion in a solution of Tween 80 at the concentration of $0.5 \%$. Afterwards, 10 dilutions were prepared at growing rate of $86.22 \mu \mathrm{g} \mathrm{mL}{ }^{-1}$, with the ability of larval locomotion for respiration as the survival criterion. Assessments of the surviving larvae were made 24,48 and 72 hours after inoculation, to safely avoid the emergence of adult mosquitoes.

\section{Statistical data analyses}

The percentages of larval death for each replication were transformed by the arc-sine square root of its proportions, and its normality was verified by a $\mathrm{K}^{2}$ test, based on the deviations from symmetry and kurtosis of the probability distribution curve of the data obtained in relation to the null hypothesis of a normal distribution. Another assumption for parametric tests, homogeneity of variance was verified by the Bartlett test [38].

Since mortality rates could not be normalized by arcsine transformation, an ordinal logistic regression was performed, taking the dose and duration of exposure to the essential oil as independent variables and larval mortality rates as the dependent variable. The null hypothesis tested was that the larval mortality rate was independent of dose or time of exposure to essential oil. Odds ratios were estimated for each analyzed parameter [38]. The $\mathrm{LC}_{50}$ was calculated from the equation of straight line generated by the linear model tested [39].

\section{Genotoxicity testing}

S. typhimurium ATCC 14028 was exposed to essential oil at the concentration of $862.20 \mathrm{mg} \mathrm{mL}^{-1}$ dispersed in Bovine Brain Heart Infusion Broth - BHI. Bioassays were made in triplicates using only BHI broth as the control, and a blank assay containing the broth medium and Tween 80 at $0.5 \%$, as surfactant, in the Laboratory of Environmental Microbiology and Biotechnology, at UVV.

Inocula were made by suspending the microorganism in water, at standard 1 in Macfarland's scale, from which $100 \mu \mathrm{L}$ were inoculated in BHI broth, and then incubated at $37^{\circ} \mathrm{C}$ for 24 hours. Afterwards, $10 \mu \mathrm{L}$ of this broth were inoculated in triplicates on BHI solid medium, for the control, blank and exposed microorganisms, and then incubated at $37^{\circ} \mathrm{C}$ for 24 hours.

Bacteria isolated from those treatments were evaluated concerning their colonial morphology and their biochemical capacity of acid production by the use of lysine, ornithine, and arginine. All inocula for biochemical testing were prepared from the same 18-24 hours subculture from a BHI agar, in a MicroScan WalkAway $968^{\circ}$, in Laboratory of Microbiology, at Tommasi Laboratório.

\section{Results and discussion}

\section{Essential oil extraction purification and density}

determination

After purification, $10.25 \mathrm{~mL}$ of essential oil were obtained, with a density of $0.8622 \mathrm{~g} \mathrm{~mL}^{-1}$, representing $3.54 \%$ yield of fresh fruits. This result was different from that found by 
Cole [40] who obtained a specific gravity of $0.9097 \pm 0.02$ g.mL $\mathrm{m}^{-1}$. This was probably because of changes in the quantity and quality of the oil constituents caused by different environmental factors related to soil, sun exposure, amount of water and other external factors.

\section{Chromatographic Analysis}

The separation of the essential oil components revealed that the chromatographic profile (Figure 1) was predominantly composed of terpenic compounds (Table 1) in total $86.51 \%$, and having as the main constituents $\delta$-3carene $(55.43 \%)$, the $\alpha$-pinene $(16.25 \%)$, the sylvestrene
Table 1 Major constituents of essential oil from fruits of Schinus terebinthifolia Raddi, determined by gas chromatography coupled to mass spectrometry

\begin{tabular}{cccc}
\hline \multicolumn{2}{c}{ Kovats indices } & Substance & (\%) \\
Calculated & Adams [36] & & \\
\hline 1013 & 1011 & $\delta$-3-carene & 55.43 \\
936 & 939 & $\alpha$-pinene & 16.25 \\
1029 & 1027 & sylvestrene & 10.67 \\
1477 & 1480 & germacrene D & 2.17 \\
991 & 991 & $\beta$-mircene & 1.99 \\
1087 & 1086 & isoterpinolene & 1.40 \\
\hline
\end{tabular}

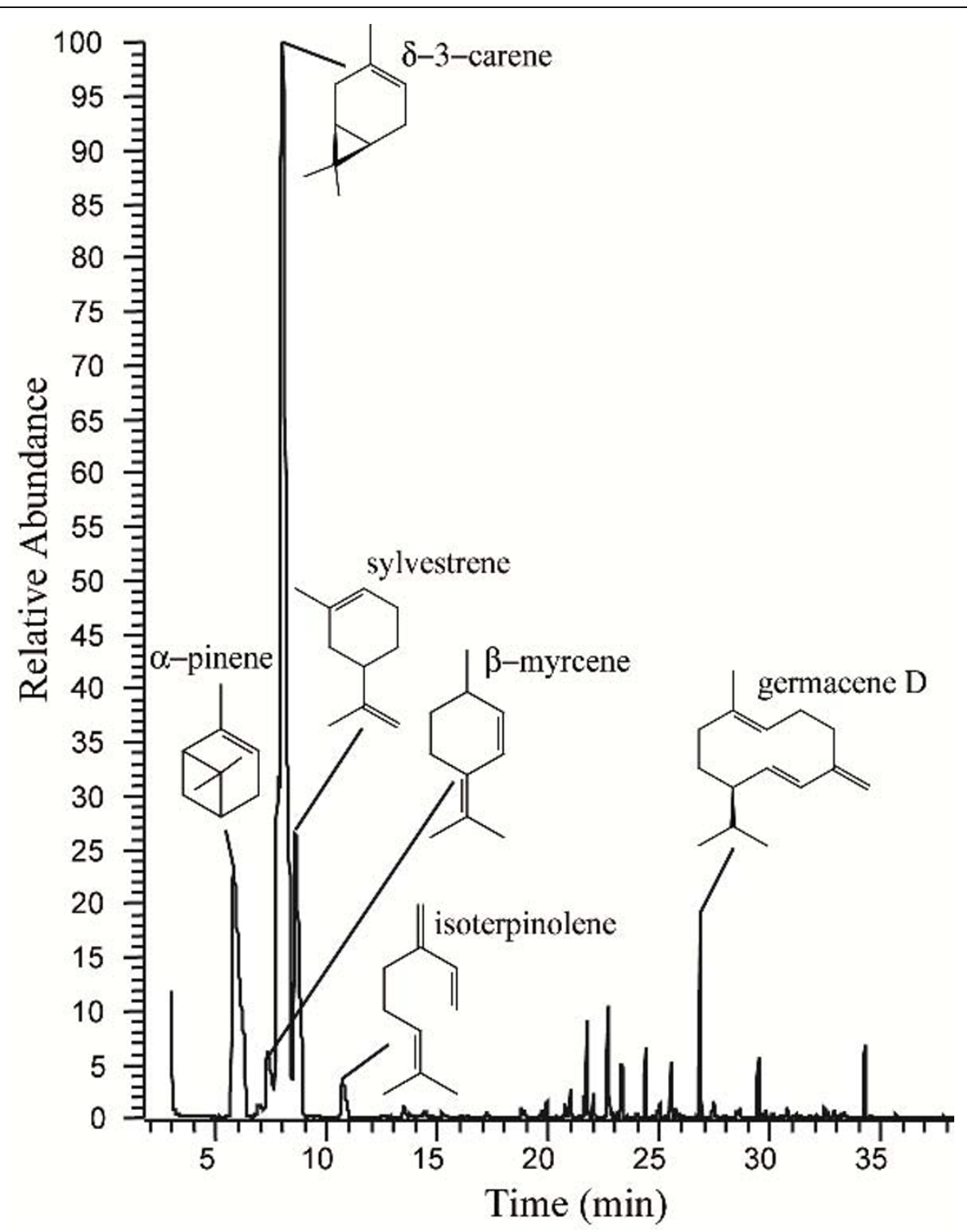

Figure 1 Chromatographic profile and chemical structure of major constituents of the essential oil from fruits and seeds of Schinus terebinthifolia. 
(10.67\%). Among the minor components are sesquiterpenic compounds $(2.17 \%)$, such as the $\beta$-myrcene (1.99\%).

One of first studies with Brazilian pepper essential oil reported that its main constituents were $\alpha$-pinene (12.94\%), $\beta$-pinene (5.02\%), $\alpha$-phellandrene (13.04\%), $\delta$ 3 -carene (29.22\%) and $\beta$-phellandrene (18.08\%) [41]. Another study shows that the major components of the oil were $\delta$-3-carene (30.37\%), limonene (17.44\%), $\alpha$-phellandrene (12.60\%), $\alpha$-pinene (12.59\%), myrcene (5.82\%), and $o$-cymene $(3.46 \%)$ [40]. In other study the main constituents were sabinene, $\alpha$-pinene, caryophyllene and germacrene D [42].

These qualitative and quantitative variations in this essential oil components may be related to the environmental conditions to which the plant is exposed such as mineral and water supply and sunlight [40].

\section{Bioassay with larvae of Stegomyia aegypti}

The minimum inhibitory dose to larval mortality was $862.20 \mu \mathrm{g} \mathrm{mL}^{-1}$ and near $50 \%$ of the larvae death occurred between the essential oil concentrations of 172.44-344.88 $\mu \mathrm{g} \mathrm{mL}^{-1}$. There was no larval mortality in the control, even after 72 hours (Table 2). Other studies have shown that the $\mathrm{LD}_{50}$ of the essential oil of $S$. terebinthifolia Raddi was $117.34 \mu \mathrm{g} \mathrm{mL}^{-1}$ [40], which did not correspond to the value found in this study. This fact may be closely related to the oil density, as a reflex of the qualitative and quantitative change in the concentrations of their constituents that may influence the calculation of median lethal dose [36,40].

Binary logistic regression (Table 3) demonstrated that larval mortality of $S$. aegypti, in spite of being high significantly affected by the concentration of the essential oil and by the incubation time, the interaction between them was not significant. The model that contained the essential oil concentration and the incubation time, without the interaction between them, as well as the models using those two variables independently were highly significant. However, the odds ratio values near 1.00 indicates a low prediction power for mortality for both of them, although the incubation time had showed a better fit to experimental data (Hosmer $\chi^{2}=0.004, p=0.95$ ).

This result shows that the larvae are susceptible to the essential oil composition, and the use of natural products can be considered an important alternative for the control of the mosquitoes, since they are biodegradable and do not harm the environment.

\section{Genotoxicity test}

After exposure of the microorganism to the essential oil, we observed no differences in colony morphology in sub-cultures obtained from control, test, and blank tubes. The colonies remained smooth, opalescent and light brightness colonies.

There was also no change in the pattern of the biochemical profile of S. typhimurium, for both microorganisms from the control and blank sub-cultures, and those ones obtained from exposure to the essential oil. They preserved their metabolism, typically positive for lysine and ornithine, and negative for arginine.

\section{Conclusion}

The density presented by the oil on which this study was based was 0.8622 g.mL $\mathrm{m}^{-1}$ which does not correspond to the density values found in other references, a fact explained by the oil composition differs with regard to quantity concentration of major constituents of the oil.

Gas chromatography coupled with mass spectroscopy (GC-MS) revealed six major constituents: $\delta$-3-carene

Table 2 Larval mortality of Stegomyia aegypti (Linnaeus, 1762) in a concentration gradient of the essential oil from fruits and seeds of Schinus terebinthifolia Raddi, the Brazilian pepper, in a $\mathbf{7 2}$ hour long bioassay

\begin{tabular}{|c|c|c|c|}
\hline \multirow[t]{2}{*}{ essential oil gradient concentration $\left(\mu \mathrm{g} \mathrm{mL}^{-1}\right)$} & \multicolumn{3}{|c|}{ Larval mortality (\% Mean \pm SE) } \\
\hline & $24 \mathrm{~h}$ & $48 \mathrm{~h}$ & $72 \mathrm{~h}$ \\
\hline Control & $0.00 \pm 0.00$ & $0.00 \pm 0.00$ & $0.00 \pm 0.00$ \\
\hline Blank & $0.00 \pm 0.00$ & $4.00 \pm 4.00$ & $4.00 \pm 4.00$ \\
\hline 86.22 & $0.00 \pm 0.00$ & $2.00 \pm 2.00$ & $4.00 \pm 2.45$ \\
\hline 172.44 & $42.00 \pm 22.00$ & $48.00 \pm 19.85$ & $52.00 \pm 18.00$ \\
\hline 258.66 & $26.00 \pm 19.39$ & $32.00 \pm 17.45$ & $32.00 \pm 22.00$ \\
\hline 344.88 & $24.00 \pm 12.08$ & $38.00 \pm 14.97$ & $42.00 \pm 18.85$ \\
\hline 431.10 & $74.00 \pm 14.00$ & $82.00 \pm 9.17$ & $88.00 \pm 8.00$ \\
\hline 517.32 & $60.00 \pm 24.49$ & $64.00 \pm 22.27$ & $64.00 \pm 22.27$ \\
\hline 603.54 & $60.00 \pm 24.49$ & $62.00 \pm 23.32$ & $64.00 \pm 22.27$ \\
\hline 689.76 & $62.00 \pm 23.32$ & $64.00 \pm 22.27$ & $68.00 \pm 19.85$ \\
\hline 775.98 & $80.00 \pm 20.00$ & $80.00 \pm 20.00$ & $82.00 \pm 18.00$ \\
\hline 862.20 & $100.00 \pm 0.00$ & $100.00 \pm 0.00$ & $100.00 \pm 0.00$ \\
\hline
\end{tabular}


Table 3 Binary logistic regression of larval mortality of Stegomyia aegypti (Linnaeus, 1762), considering the influence of concentration of Brazilian pepper, Schinus terebinthifolia Raddi, essential oil and the incubation time

\begin{tabular}{|c|c|c|c|c|c|c|c|}
\hline \multirow[t]{2}{*}{ Model } & \multirow[t]{2}{*}{ Coefficient } & \multirow[t]{2}{*}{ Standard Error } & \multirow[t]{2}{*}{$Z$} & \multirow[t]{2}{*}{$p$} & \multicolumn{3}{|c|}{ Odds Ratio and limits (95\%) } \\
\hline & & & & & Ratio & Inferior & Superior \\
\hline \multicolumn{8}{|c|}{ Interaction of essential oil concentration and Incubation time } \\
\hline Constant & -2.889 & 0.334 & -8.65 & $0.00^{* *}$ & & & \\
\hline Concentration & 0.006 & 0.001 & 8.70 & $0.00^{* *}$ & 1.01 & 1.00 & 1.01 \\
\hline Time & 0.020 & 0.006 & 3.22 & $0.00^{* *}$ & 1.02 & 1.01 & 1.03 \\
\hline Concentration $\times$ Time & 0.000 & 0.000 & -1.87 & $0.06^{\mathrm{ns}}$ & & & \\
\hline \multicolumn{8}{|c|}{$\mathrm{G}=514.5 ; p<0.01 . \mathrm{df}=3 ;$ Hosmer $\chi^{2}=82.65 . p<0.01^{* *}$} \\
\hline \multicolumn{8}{|c|}{ Essential oil concentration + incubation time } \\
\hline Constant & -2.392 & 0.193 & -12.42 & $0.00^{* *}$ & & & \\
\hline Concentration & 0.005 & 0.000 & 19.20 & $0.00^{* *}$ & 1.00 & 1.00 & 1.01 \\
\hline Time & 0.010 & 0.003 & 3.26 & $0.00^{* *}$ & 1.01 & 1.00 & 1.02 \\
\hline \multicolumn{8}{|c|}{$\mathrm{G}=$ 510.96. $p<0.01 . \mathrm{df}=2 ;$ Hosmer $\chi^{2}=57.26 ; p<0.01^{* *}$} \\
\hline \multicolumn{8}{|c|}{ Essential oil concentration } \\
\hline Constant & -1.911 & 0.118 & -16.20 & $0.00^{* *}$ & & & \\
\hline Concentration & 0.005 & 0.000 & 19.20 & $0.00^{* *}$ & 1.00 & 1.00 & 1.01 \\
\hline \multicolumn{8}{|c|}{$\mathrm{G}=$ 500.25. $p<0.01 . \mathrm{df}=1$; Hosmer $\chi^{2}=87.03 . p<0.01^{* *}$} \\
\hline \multicolumn{8}{|l|}{ Incubation time } \\
\hline Constante & -0.246 & 0.131 & -1.88 & $0,06^{\mathrm{ns}}$ & & & \\
\hline Time & 0.007 & 0.003 & 2.77 & $0,01^{* *}$ & 1.00 & 1.00 & 1.01 \\
\hline \multicolumn{8}{|c|}{$\mathrm{G}=7.72 . p<0.01 . \mathrm{df}=1 ;$ Hosmer $\chi^{2}=0.004 \cdot p=0.95^{\mathrm{ns}}$} \\
\hline
\end{tabular}

Z: standard coefficient; $p$ : significance level; **highly significant; df: degrees of freedom.

(55.43\%), $\alpha$-pinene (16.25\%), sylvestrene (10.67\%), germacrene $\mathrm{D}$ (2.17), $\beta$-myrcene (1.99\%), and isoterpinolene $(1.4 \%)$. Those major compounds, when added together represent $86.51 \%$ of the essential oil of $S$. terebinthifolia.

The larval median lethal dose $\left(\mathrm{LD}_{50}\right)$ of the essential oil was between the concentrations of 172.44-344.88 $\mu \mathrm{g}$ $\mathrm{mL}^{-1}$; there was no larvae mortality in the control, even after 72 hours. This value is not in accordance with previous studies, possibly because of the density value, constituents and concentrations of constituents in the oil.

There was no effect of the essential oil from the fruits of S. terebinthifolia on aspects of the biochemistry or morphological changes in the experiment with $S$. typhimurium.

\section{Acknowledgements \\ We acknowledge the Center for Zoonosis Control from the Health Department, at Vitoria, Espírito Santo State, Brazil, for supplying S. aegypti eggs that hatched the larvae used in our biological assay; the Centro Universitário Vila Velha - UW, and the laboratories Tommasi Analitica and Tommasi Laboratório for technological support for the larval bioassay, and microbiological and chromatographic analyses, respectively; Roy Funch for revising the final English version; and two anonymous referees whose comments were fundamental to improve the original manuscript.}

\section{Author details}

${ }^{1}$ Centro Universitário Vila Velha - UW. Rua Comissário José Dantas de Melo, 21, Boa Vista, Vila Velha, ES, CEP 29.102-770, Brazil. Tommasi Laboratório. Rua Araribóia, 322, Centro, Vila Velha, ES, CEP.: 29100-340, Brazil. ${ }^{3}$ Tommasi
Analítica. Avenida Luciano das Neves, 2016, Divino Espírito Santo, Vila Velha, ES, CEP. 29.107-010, Brazil.

\section{Authors' contributions}

AGS carried out the statistical data analyses as well as the extraction, purification, and chemical analysis of essential oil, microbiological and larvae bioassays. DLA and SNR carried out the extraction, purification, and chemical analysis of essential oil, microbiological and larval bioassays; ACM and ACR carried out the microbiological analysis, RS carried out the gas chromatography analysis, ZMAC carried out the larval bioassays. All authors read and approved this final manuscript.

\section{Competing interests}

The authors declare that they have no competing interests.

Received: 7 July 2010 Accepted: 27 August 2010

Published: 27 August 2010

\section{References}

1. Lourenço-de-Oliveira R, Vazeille M, Filippis AMB, Failloux AB: Aedes aegypti in Brazil: genetically differentiated populations with high susceptibility to dengue and yellow fever viruses. Trans R Soc Trop Med Hyg 2004, 98:43-54.

2. Halstead SB: Dengue: overview and history. In Dengue. Edited by: Halstead SB. London: Imperial College Press; 2008:1-28, [Pasvol G, Hoffman SL (series Editors) Tropical Medicine: Science and Practices, vol 5].

3. Suaya JA, Shepard DS, Siqueira JB, Martelli CT, Lum LCS, Tan LH, Kongsin S, Jiamton S, Garrido F, Montoya R, Armien B, Huy R, Castillo L, Caram M, Sah BK, Sughayyar R, Tyo KR, Halstead SB: Cost of dengue cases in eight countries in the americas and asia: a prospective study. Am J Trop Med Hyg 2009, 80:846-855.

4. Chiaravalloti-Neto F: Descrição da colonização de Aedes aegypti na região de São José do Rio Preto, SP. Rev Soc Bras Med Trop 1997, 30:279-285.

5. Reinert JF, Harbach RE, Kitching IJ: Phylogeny and classification of Aedini (Diptera: Culicidae), based on morphological characters of all life stages. Zool J Linn Soc 2004, 142:289-368. 
6. Neves AP, Melo AL, Genaro O, Linardi PM: Parasitologia Humana São Paulo: Atheneu 2007.

7. Teixeira MC, Barreto ML, Costa MCN, Ferreira LDA, Vasconcelos PFC: Avaliação de impacto de ações de combate ao Aedes aegypti na cidade de Salvador, Bahia. Rev Bras Epidemiol 2002, 5:108-115.

8. Fundação Nacional da Saúde: Dengue: instruções para pessoal de combate ao vetor, manual de normas técnicas. Brasília: Funasa, 32001.

9. Lenzi MF, Coura LC: Prevenção da dengue: a informação em foco. Rev Soc Bras Med Trop 2004, 37:343-350.

10. Guya B, Guirakhooa F, Barbana V, Higgsb S, Monathc TP, Langa J: Preclinical and clinical development of YFV 17D-based chimeric vaccines against dengue, West Nile and Japanese encephalitis viruses. Vaccine 2010, 28:632-649.

11. Horsticka O, Runge-Ranzingerb $S$, Nathanc MB, Kroegera A: Dengue vectorcontrol services: how do they work? A systematic literature review and country case studies. Trans R Soc Trop Med Hyg 2010, 104:379-386.

12. Cavalcanti LPG, Pontes RJS, Regazzi ACF, Júnior FJP, Frutuoso RL, Sousa EP, Filho FFD, Lima JWO: Competência de peixes como predadores de larvas de Aedes aegypti, em condições de laboratório. Rev Saúde pública 2007, 41:638-644.

13. Silva $H H G$, Silva IG, Santos RMG, Rodrigues EF, Elias CN: Atividade larvicida de taninos isolados de Magonia pubescens St. Hil. (Sapindaceae) sobre Aedes aegypti (Diptera, Culicidae). Rev Soc Bras Med Trop 2004, 37:396-399.

14. Bakkali F, Averbeck S, Averbeck D, Idaomar M: Biological effects of essential oils - A review. Food Chem Toxicol 2008, 46:446-475.

15. Katz TM, Miller $\mathrm{JH}$, Hebert AA: Insect repellents: historical perspectives and new developments. J Am Acad Dermatol 2008, 58:865-871.

16. Shaalan EAS, Canyon D, Younes MWF, Abdel-Wahab H, Mansour AH: A review of botanical phytochemicals with mosquitocidal potential. Environ Int 2005, 31:1149-1166.

17. Ciccia G, Coussio J, Mongelli E: Insecticidal activity against Aedes aegypti larvae of some medicinal South American plants. J Ethnopharmacol 2000, 72:185-189.

18. Omena MC, Navarro DMAF, Paula JE, Luna JS, Ferreira de Lima MR, Sant'Ana AEG: Larvicidal activities against Aedes aegypti of some Brazilian medicinal plants. Bioresour Technol 2007, 98:2549-2556.

19. Oliveira PV, Ferreira JC Jr, Moura FS, Lima GS, Oliveira FM, Oliveira PES, Conserva LM, Giulietti AM, Lemos RPL: Larvicidal activity of 94 extracts from ten plant species of northeastern of Brazil against Aedes aegypti $\mathrm{L}$. (Diptera: Culicidae). Parasitol Res 2010, 107:403-407.

20. Mendonça FAC, Silva KFS, Santos KK, Ribeiro KAL Jr, Sant'Ana AEG Activities of some Brazilian plants against larvae of the mosquito Aedes aegypti. Fitoterapia 2005, 76:629-636.

21. Simas NK, Lima EC, Conceição SR, Kuster RM, Oliveira-Filho AM, Lage CLS: Produtos naturais para o controle da transmissão da dengue - atividade larvicida de Myroxylon balsamum (Óleo Vermelho) e de terpenóides e fenilpropanóides. Quím nova 2004, 27:46-49.

22. Cavalcanti ESB, Morais SM, Lima MAA, Santana EWP: Larvicidal activity of essential oils from Brazilian plants against Aedes aegypti L. Mem Inst Oswaldo Cruz 2004, 99:541-544.

23. Furtado RF, Lima MGA, Andrade Neto Manoel, Bezerra JNS, Silva MGV: Atividade larvicida de óleos essenciais contra Aedes aegypti L. (Diptera: Culicidae). Neotrop Entomol 2005, 34:843-847.

24. Lima MGA, Maia ICC, Sousa BD, Morais SM, Freitas SM: Effect of stalk and leaf extracts from Euphorbiaceae species on Aedes aegypti (Diptera, Culicidae) larvae. Rev Inst Med trop S Paulo 2006, 48:211-214.

25. Morais SM, Facundo VA, Bertini LM, Cavalcanti ESB, Anjos JF Jr, Ferreira SA Brito ES, Souza Neto MA: Chemical composition and larvicidal activity of essential oils from Piper species. Biochem Syst Ecol 2007, 670-675.

26. Porto KRA, Roel AR, Silva MM, Coelho RM, Scheleder EJD, Jeller AH: Atividade larvicida do óleo de Anacardium humile Saint Hill sobre Aedes aegypti (Linnaeus, 1762) (Diptera, Culicidae). Rev Soc Bras Med Trop 2008, 41:586-589.

27. Silva WJ, Dória GAA, Maia RT, Nunes RS, Carvalho GA, Blank AF, Alves PB, Marçal RM, Cavalcanti SCH: Effects of essential oils on Aedes aegypti larvae: alternatives to environmentally safe insecticides. Biochem Syst Ecol 2007, 35:670-675.

28. Lenzi M, Orth Al: Fenologia reprodutiva, morfologia e biologia floral de Schinus terebinthifolius Raddi (Anacardiaceae), em restinga da llha de Santa Catarina, Brasil. Biotemas 2004, 17:67-89.
29. Degáspari $\mathrm{CL}$, Waszczynskyj N: Propriedades antimicrobianas dos frutos da aroeira (Schinus terebenthifolius Raddi). Ciência e Agrotecnologia 2005, 29:617-622.

30. Pires OC, Taquemasa AVC, Akisue G, Oliveira F, Araújo CEP: Preliminary comparative analysis of the acute toxicity and median lethal dose of the fruit of the Brazilian black pepper (Schinus terebinthifolius Raddi) and black pepper (Piper nigrum L.). Latin Am J Pharm 2004, 23:176-182.

31. Santos LC, Amorim MMR: Uso da aroeira (Schinus terebinthifolius Raddi) para tratamento de infecções vaginais. Femina 2002, 30:339-420.

32. Mourelle JAF: Anti-inflammatory activity of Schinus terebinthifoluis (Copal) in rats. Rev Cuba Farm 1993, 27:139-144.

33. Jain MK, Yu BZ, Rogers JM: Specific competitive inhibitor of secreted phospholipase $A_{2}$ from berries of Schinus terebinthifolius. Phytochemistry 1995, 39:537-547.

34. Martinez MJ, Betancourt J, Alonso-Gonzalez N, Jauregui A: Screening of some Cuban medicinal plants for antimicrobial activity. J Ethnopharmacol 1996, 5:171-174.

35. Siddiqui R, Zunino MP, Zygadlo JA: Tagetes minuta and Schinus areira essential oils as allelopathic agents. Biochem Syst Ecol 2003, 31:563-572.

36. Adams RP: Identification of essential oil components by gas chromatography/mass spectrometry. Carol Stream: Allured Publishing Corporation, 42009.

37. Nascimento AM, Almeida DL, Lima EM, Ronchi SN, Cruz ZMA, Silva AG: Mophomutagenesis risk and larvicidal activity of the essential oil of Christmas berry, Schinus terebinthifolia Raddi against Aedes aegypti. Natureza on line 2008, 6:86-90.

38. Zar JH: Biostatistical analysis New Jersey: Prentice Hall 2008.

39. Hosmer DW, Lemeshow S: Applied logistic regression New York: John Wiley 1989.

40. Cole ER: Estudo fitoquímico do óleo essencial dos frutos da aroeira (Schinus terebinthifolius RADDI) e sua eficácia no combate ao dengue. MSc dissertation Federal University of the Espírito Santo - Brazil, Department of Chemistry, Center of Exact Sciences 2008

41. Clemente AD: Estudo fitoquímico do óleo essencial dos frutos da aroeira (Schinus terebinthifolius Raddi) e sua eficácia no combate ao dengue. MSc dissertation Federal University of the Viçosa - MG - Brazil, Department of chemistry 2006

42. Dos Santos ACA, Rossato M, Agostini F, Dos Santos PL, Serafini LA, Moyna P, Dellacassa E: Avaliação química mensal de três exemplares de Schinus terebinthifolius Raddi. Rev Bras Biociências 2007, 5:1011-1013.

doi:10.1186/1756-3305-3-79

Cite this article as: Silva et al:: The essential oil of Brazilian pepper,

Schinus terebinthifolia Raddi in larval control of Stegomyia aegypti (Linnaeus, 1762). Parasites \& Vectors 2010 3:79.

\section{Submit your next manuscript to BioMed Central and take full advantage of:}

- Convenient online submission

- Thorough peer review

- No space constraints or color figure charges

- Immediate publication on acceptance

- Inclusion in PubMed, CAS, Scopus and Google Scholar

- Research which is freely available for redistribution

Submit your manuscript at www.biomedcentral.com/submit
C Biomed Central 